\title{
$\varnothing$ \\ Size distribution and total number concentration of ultrafine and accumulation mode particles and hospital admissions in children and the elderly in Copenhagen, Denmark
}

\author{
Z J Andersen, ${ }^{1,2} \mathrm{P}$ Wahlin, ${ }^{3} 0$ Raaschou-Nielsen, ${ }^{4} \mathrm{M}$ Ketzel, ${ }^{3} \mathrm{~T}$ Scheike, ${ }^{1} \mathrm{~S}$ Loft ${ }^{2}$
}

${ }^{1}$ Department of Biostatistics, University of Copenhagen,

Copenhagen, Denmark;

${ }^{2}$ Department of Environmental and Occupational Health, University of Copenhagen,

Copenhagen, Denmark;

${ }^{3}$ Department of Atmospheric

Environment, National

Environmental Research

Institute, Aarhus University,

Århus, Denmark; ${ }^{4}$ Institute of

Cancer Epidemiology, The

Danish Cancer Society,

Copenhagen, Denmark

Correspondence to:

Zorana J Andersen, Department

of Biostatistics, Institute of

Public Health, Copenhagen

University, Øster Farimagsgade,

5 Entr. B, PO Box 2099, 1014

Copenhagen K, Denmark;

zorana@cancer.dk

Accepted 25 October 2007

Published Online First

7 November 2007

\begin{abstract}
Objectives: To study the association between short-term exposure to ultrafine particles and morbidity in Copenhagen, Denmark.

Methods: We studied the association between urban background levels of the total number concentration of particles $\left(\mathrm{NC}_{\text {tot }}, 6-700 \mathrm{~nm}\right.$ in diameter) measured at a single site (15 May 2001 to 31 December 2004) and hospital admissions due to cardiovascular (CVD) and respiratory disease (RD) in the elderly (age $\geqslant 65$ years), and due to asthma in children (age 5-18 years). We examined these associations in the presence of $\mathrm{PM}_{10}$, $\mathrm{PM}_{2.5}$ (particulate matter $<10$ and $2.5 \mu \mathrm{m}$ in diameter, respectively) and ambient gasses. We utilised data on size distribution to calculate $\mathrm{NC}_{\text {tot }}$ for four modes with median diameters 12, 23, 57 and $212 \mathrm{~nm}$, and $\mathrm{NC}_{100}$ (number concentration of particles $<100 \mathrm{~nm}$ in diameter) and examined their associations with health outcomes. We used a time series Poisson generalised additive model adjusted for overdispersion, season, day of the week, public holidays, school holidays, influenza, pollen and meteorology, with up to 5 days' lagged exposure.
\end{abstract}

Results and conclusions: The adverse health effects of particulate matter on CVD and RD hospital admissions in the elderly were mainly mediated by $\mathrm{PM}_{10}$ and accumulation mode particles with lack of effects for $\mathrm{NC}_{100}$. For paediatric asthma, accumulation mode particles, $\mathrm{NC}_{100}$ and nitrogen oxides (mainly from traffic related sources) were relevant, whereas $\mathrm{PM}_{10}$ appeared to have little effect. Our results suggest that particle volume/mass from long-range transported air pollution is relevant for CVD and RD admissions in the elderly, and possibly particle numbers from traffic sources for paediatric asthma.

Numerous studies have established evidence of associations between particulate matter (PM) and mortality and morbidity in adults and morbidity in children. ${ }^{12}$ However, which properties of ambient aerosols are responsible for health effects remains unclear. Much of the current discussion concerns particle size, an important determinant of the site and efficiency of pulmonary deposition, and a surrogate for particle source and composition. In the last few decades, airborne particles have mainly been characterised by measurements of mass of two size cuts, mostly $\mathrm{PM}_{10}$ (particulate matter $<10 \mu \mathrm{m}$ in diameter) and more recently $\mathrm{PM}_{2.5}$ (particulate matter $<2.5 \mu \mathrm{m}$ in diameter; fine particles, FPs). The particle size range less than $0.1 \mu \mathrm{m}$ in diameter, known as ultrafine particles
(UFPs), is a unique fraction which, compared to larger PM fractions, contributes to magnitudes higher particle numbers and very little to mass. ${ }^{3}{ }^{4}$ The role of UFPs has mostly been addressed in toxicological studies, which showed a number of characteristics and patterns of reactivity specific to UFPs and different from larger particles, including inducing the greatest amount of inflammation per unit PM mass, greater internal doses due to high lung deposition efficiency, enhanced oxidant capacity, and the ability to induce oxidative DNA damage and possibly to enter the systemic circulation in humans. ${ }^{3-12}$ This toxicological evidence indicates that some of the adverse PM health effects reported in epidemiological studies may be mediated by UFPs. ${ }^{13}$ Only recently, following advances in measuring techniques, could epidemiological designs focus on UFPs, giving modest and mixed evidence and suggesting effects independent of those of FPs. ${ }^{3}$ Substantial evidence on UFP health effects comes from studies on multi- and single-site panels of patients with asthma and heart disease with short (months) urban background measurement campaigns. ${ }^{14-22}$ Two mortality time series studies with 3 and 6 years' urban background measurements of UFPs from Erfurt, ${ }^{23}{ }^{24}$ two multi-city time series studies on myocardial infarction, ${ }^{25} 26$ and a case-crossover study of coronary out-of-hospital deaths in Rome, ${ }^{27}$ with partly modelled exposure assessment, complete the epidemiological evidence of the health effects of UFPs. These studies vary in design, health outcomes and exposure assessment, address size distribution only to a limited extent, and offer conflicting evidence of the importance of UFPs. Hospital admissions for respiratory diseases are yet to be studied as a health outcome. As the identification of PM size fraction and properties most relevant to health can lead to important clues to biological mechanisms and more efficient control, more studies on the health effects of the smallest and least understood PM fraction, UFPs, are urgently needed.

In this paper we studied the effect of the total number concentration of ultrafine and accumulation mode particles $\left(\mathrm{NC}_{\text {tot }}\right)$ on hospital admissions in the presence of $\mathrm{PM}_{10}, \mathrm{PM}_{2.5}$ and gaseous pollutants (carbon monoxide (CO), nitrogen dioxide $\left(\mathrm{NO}_{2}\right)$, ozone $\left.\left(\mathrm{O}_{3}\right)\right)$. We furthermore assigned $\mathrm{NC}_{\text {tot }}$ to four size modes with presumed different sources and properties to evaluate which are most relevant to health, and examined the role of $\mathrm{NC}_{100}$ 
(number concentration of particles $<100 \mathrm{~nm}$ in diameter) which was derived from the four size modes. We studied three health outcomes, hospital admissions due to cardiovascular disease $(C V D)$ in the elderly (age $\geqslant 65$ ), respiratory disease (RD) in the elderly (age $\geqslant 65$ ) and asthma in school-aged children (518 years), covering the array of diseases and susceptible populations and allowing for direct comparison across diseases and pollutants, with a focus on UFPs and accumulation mode particles.

\section{METHODS \\ Health outcomes}

We defined three health outcomes based on the International Classification of Diseases, Tenth Revision (ICD-10), ${ }^{28}$ so that CVD hospital admissions in the elderly (age $\geqslant 65$ years) include angina pectoris (I20), myocardial infarction (I21-22), other acute ischaemic heart diseases (I24), chronic ischaemic heart disease (I25), pulmonary embolism (I26), cardiac arrest (I46), cardiac arrhythmias (I48-49) and heart failure (I50); RD hospital admissions in the elderly (age $\geqslant 65$ years) include chronic bronchitis (J41-42), emphysema (J43), other chronic obstructive pulmonary disease (COPD; J44), asthma (J45) and status asthmaticus (J46); and paediatric asthma admissions (518 years) include asthma (J45) and status asthmaticus (J46). All hospital admissions with these ICD codes as admission diagnoses were included, which implies that up to $2 \%$ and $20 \%$ of planned admissions were for respiratory and cardiovascular diagnoses, respectively. We extracted daily counts of hospital admissions from the Danish Hospital Register for the 3.5-year (1327 days) period (15 May 2001 to 31 December 2004) in nine hospitals within a $15 \mathrm{~km}$ (average of $6 \mathrm{~km}$ ) radius of the background monitoring station, which service a population of approximately 1.5 million people.

\section{Exposure monitoring and meteorology}

The pollutant and meteorological data for the main analyses were measured using a fixed urban background monitor (15 May 2001 to 31 December 2004) located on the roof of a $20 \mathrm{~m}$ high building in a park in the centre of Copenhagen, about $300 \mathrm{~m}$ east and $50 \mathrm{~m}$ west of two streets with typical weekday traffic flows of 26000 and 56000 vehicles, respectively. The monitor was placed at a location with minimal contribution from local pollution sources in accordance with WHO guidelines. ${ }^{29}$ Daily (24 h, midnight-to-midnight) $\mathrm{NC}_{\text {tot }}$ and mean size distributions (6-700 $\mathrm{nm}$ in diameter) were measured by a DMPS (differential mobility particle sizer) as described elsewhere. ${ }^{30}$ Additionally, daily mean concentrations were available for $\mathrm{PM}_{10}$ (beta attenuation by an SM 200 monitor; Opsis, Furulund, Sweden), CO (M 300 monitor; API, San Diego, USA), $\mathrm{NO}_{2}$ and $\mathrm{NO}_{\mathrm{x}}$ (M 200A; API), $\mathrm{O}_{3}$ (M400; API), temperature and relative humidity. Measurements of $\mathrm{PM}_{2.5}$ (TEOM Ambient Particulate Monitor; Rupprecht \& Patashnick, Albany, New York, USA) not corrected for losses of volatile material, were first available from 3 October 2003 when monitoring of background $\mathrm{PM}_{2.5}$ began in Copenhagen.

Measurements at a kerbside monitor located on a busy street (typical weekday traffic flow of 60000 vehicles) about $3000 \mathrm{~m}$ from the background monitor were available for $\mathrm{NC}_{\text {tot }}$ and size distributions $\mathrm{PM}_{10}$ and $\mathrm{PM}_{2.5}$ for a 105-day period (22 September 2004 to 26 December 2005), and for $\mathrm{NO}_{\mathrm{x}}$ for the whole study period (15 May 2001 to 31 December 2004). Levels at this monitor were largely independent of wind direction. Similarly, measurements of $\mathrm{NC}_{\text {tot }}$ and size distribution $\mathrm{PM}_{10}$ were available for a 47-day (22 April 2005 to 11 September 2005) period from a rural monitor located $30 \mathrm{~km}$ southwest of the urban background monitor. The kerbside and rural monitor measurements were used for assessing the spatial correlation of pollutants relevant for the discussion of exposure misclassification resulting from using pollutant measurements from the urban background monitor.

\section{Particle size distribution}

For each day, the average size distribution of particle number concentrations was fitted to a sum of four log-normal modes, a12 (median diameter $\mathrm{d}_{\mathrm{m}} 11.7 \mathrm{~nm}$, geometric standard deviation $\sigma$ 1.24), a23 (22.6 nm, 1.48), a57 (57.1 nm, 1.96) and a 212 (211.7 $\mathrm{nm}, 1.72)$. The functional dependence of a single mode on diameter $\mathrm{d}$ was defined by the formula,

$$
\exp \left(-\frac{\left(\log d-\log d_{m}\right)^{2}}{2(\log \sigma)^{2}}\right)
$$

depicted in fig 1 and explained elsewhere. ${ }^{31}$ The three smallest modes observed in the busy streets of Copenhagen ${ }^{30}{ }^{31}$ were the $\mathrm{a} 12$, the $\mathrm{a} 23$ and the $\mathrm{a} 57$. The a12 mode originates from the nucleation of sulphur compounds with low vapour pressure in exhaust systems. After exiting the exhaust pipe, these particles
Figure 1 Average size distribution of urban background $\mathrm{NC}_{\text {tot }}$ (ultrafine and accumulation mode particles 6-700 nm in diameter) resolved in four size modes (with median diameters of 12, 23, 57 and $212 \mathrm{~nm}$ ) in Copenhagen (15 May 2001 to 31 December 2004). Small circles represent observed $\mathrm{NC}_{\text {tot, }}$ the solid line represents fitted $\mathrm{NC}_{\text {tot }}$ and dashed lines represent fitted number concentration resolved in four modes.

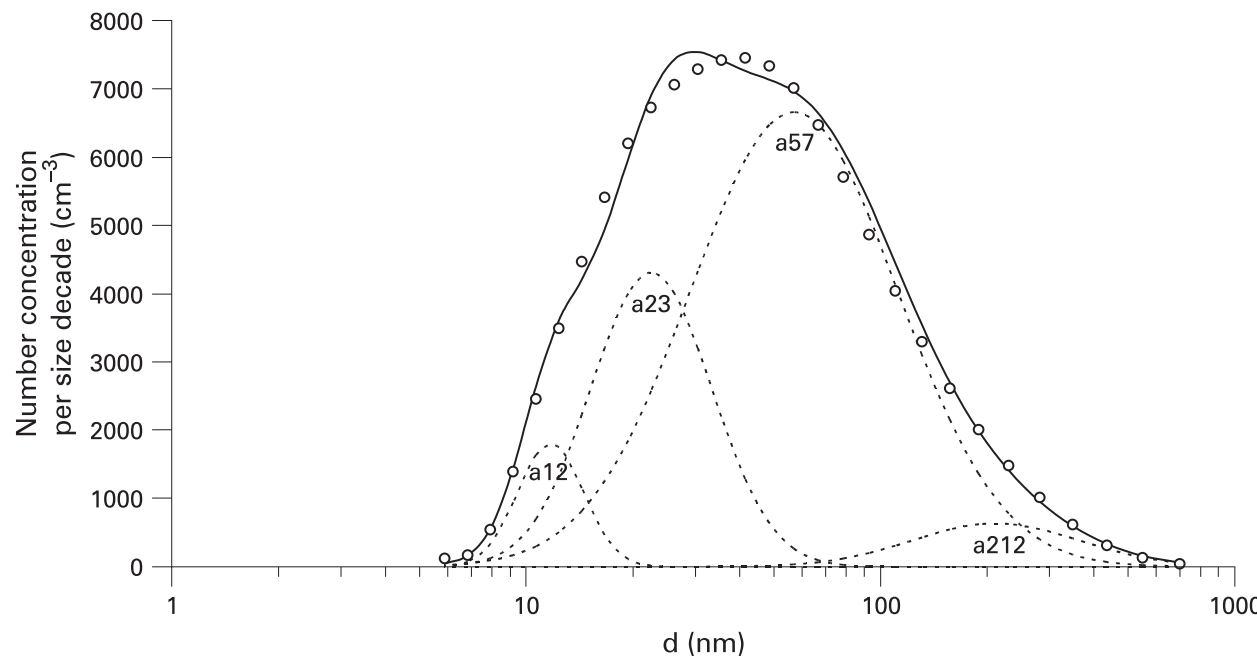


grow by condensation of volatile organic compounds, especially under cold ambient conditions. An important source of these particles is new diesel cars with oxidising converters, such as taxis. The a23 mode consists of volatile organic compounds attributed to ordinary diesel vehicles. The a57 mode represents soot and accumulation mode particles.

In the urban background in Copenhagen, approximately half of the particle numbers are due to traffic, ${ }^{30}$ while most of the rest originate from secondary long-range transported particles. These particles, especially in their younger stages, can also be categorised into the three modes discussed above. In order to also achieve acceptable fits for the particle volume distribution, it was necessary to include an additional mode at $212 \mathrm{~nm}$. The a212 mode represents aged secondary long-range transported particles and a large fraction of the particle volume (mass).

The number concentration of urban background particles $<100 \mathrm{~nm}$ in diameter $\left(\mathrm{NC}_{100}\right)$ was derived as $\mathrm{a} 12+\mathrm{a} 23+0.797^{*} \mathrm{a} 57+0.084^{*} \mathrm{a} 212$. The surface area and volume concentration of each mode were estimated from number concentration assuming uniform spherical shapes with the relevant diameters, resulting in number concentration, surface area and volume concentration being directly proportional.

\section{Influenza and pollen}

Influenza epidemics data provided by Statens Serum Institute were available as a weekly percentage of total general physician consultations due to influenza in Copenhagen. Pollen data for mugwort, birch, alder, elm, grass and hazel, as mean counts per $\mathrm{m}^{3}$ of air, were obtained from the Danish Meteorological Institute.

\section{Statistical methods}

We applied a generalised additive Poisson time series regression model adjusted for overdispersion, to estimate associations between day-to-day variations in pollutant concentrations (lag $0-5$ ) and day-to-day variations in hospital admission counts for three health outcomes separately. ${ }^{32}$ A basic model without pollutants was built first, using Akaike's information criterion, covariate response plots, partial autocorrelation in residual plots and residual plots. We controlled for weather by modelling temperature and dew-point temperature with smoothing spline functions with 4 or 5 degrees of freedom (df), while a smoothing spline of calendar time with 3, 4 or $5 \mathrm{df} /$ year was used to control for long-term trend and seasonality. Influenza (dummy for days above the 95th percentile of the percentage of weekly physician influenza consultations), day of the week, public and school holidays were included in the model via dummy variables. Only grass pollen was associated with the asthma admissions and was included in the paediatric asthma model as a continuous variable, while no pollen type was associated with CVD or RD admissions. A priori it was decided to adjust for school holidays only in the children model, assuming that school holidays would affect the admission rates for children but not for the elderly. Pollutants were introduced into the model as linear terms.

After assessing the effects of single day concentrations (lags $0-5)$, several day averages were created to include days with the strongest lag effects for $\mathrm{NC}_{\text {tot}}$, resulting in a 4-day pollutant average (lag 0-3) for CVD, a 5-day average (lag 0-4) for $\mathrm{RD}$, and a 6-day average (lag 0-5) for asthma. In the case of missing a single day's exposure, a 4-, 5- or 6-day mean of available measurements was taken. The same averages were applied to other pollutants and meteorological variables to provide for consistent comparison across the health outcome. We estimated all relative risks (RR) per interquartile range (IOR) increment in pollutants. First, we fitted one-pollutant models to examine the independent effects of each pollutant on health, and then multipollutant models, with the criterion that the highest allowed correlation coefficient between pollutants in the models was $<0.70$.

In addition, we performed analyses with hospital admissions in four Copenhagen hospitals within a $5 \mathrm{~km}$ radius of the background monitor. Finally, we performed analyses with kerbside $\mathrm{NO}_{\mathrm{x}}$ measurements as an alternative proxy of fresh traffic exhaust.

We performed analyses in the gam procedure, mgcv package in $\mathrm{R}$ statistical software. ${ }^{33}$

\section{RESULTS}

The summary statistics are presented in table 1 . The relatively short and incomplete time series of $\mathrm{NC}_{\text {tot }}$ measurements (578 days) was the result of difficulties encountered in keeping the equipment operating normally for extended periods due to water accumulation in the condensation particle counter.

The daily $24 \mathrm{~h}$ average of $\mathrm{NC}_{\text {tot }}$ was resolved in four size modes (fig 1). $\mathrm{NC}_{\mathrm{a} 57}$ (number concentration of size mode a57) was the highest of the four modes, accounting for about $63 \%$ of $\mathrm{NC}_{\text {tot }}$, followed by $\mathrm{NC}_{\mathrm{a} 23}, \mathrm{NC}_{\mathrm{a} 12}$ and $\mathrm{NC}_{\mathrm{a} 212}$ (number concentration of size modes a23, a12 and a212) accounting for $28 \%, 6 \%$ and $5 \%$ of $\mathrm{NC}_{\text {tot }}$, respectively. Modes a 57 and a 212 accounted for $61 \%$ and $46 \%$ of the surface area, and $45 \%$ and $86 \%$ of the volume of $\mathrm{NC}_{\text {tot }}$, respectively, whereas a 23 and a12 contributed minimally (see table A1 in appendix A). Assuming a $\mathrm{PM}$ density of $1.5 \mathrm{~g} / \mathrm{cm}^{3}$, the volume concentration given in $\mu \mathrm{m}^{3} / \mathrm{cm}^{3}$ corresponds to $\mu \mathrm{g} / \mathrm{m}^{3}$, and the combined mass concentration of the a57 and a 212 modes would be approximately $17 \mu \mathrm{g} / \mathrm{m}^{3}$ or about $70 \%$ of the $\mathrm{PM}_{10}$ mass concentration of $24 \mu \mathrm{g} / \mathrm{m}^{3}$. ${ }^{30}$

Urban background $\mathrm{NC}_{\text {tot }}$ was poorly correlated with $\mathrm{PM}_{10}$ $(\mathrm{r}$ (Spearman correlation coefficient $)=0.39)$ and $\mathrm{PM}_{2.5}$ $(r=0.40)$ and best correlated with $\mathrm{NO}_{2} / \mathrm{NO}_{\mathrm{x}}(\mathrm{r}=0.68 / 0.66)$. $\mathrm{PM}_{10}$ and $\mathrm{PM}_{2.5}$ were strongly correlated $(\mathrm{r}=0.80)$. Low or no correlation was found between the four $\mathrm{NC}_{\text {tot }}$ size modes. $\mathrm{NC}_{\mathrm{a} 212}$ was most strongly correlated with $\mathrm{PM}_{2.5}(\mathrm{r}=0.80)$ and $\mathrm{PM}_{10}(\mathrm{r}=0.63)$, while $\mathrm{NC}_{\mathrm{a} 57}$ correlated well with $\mathrm{NO}_{2}$ $(\mathrm{r}=0.57)$. A full table of correlations is provided in table A2 in appendix $A$.

Urban background $\mathrm{NC}_{\text {tot }}$ measurements were well correlated with measurements both at the kerbside and at rural stations, with kerbside levels being almost five times higher and rural levels 30\% lower than urban background levels (table 2). However, urban background $\mathrm{NC}_{\mathrm{a} 12}$ was poorly correlated with both kerbside and rural levels, with levels at the kerbside 25 times higher than the urban background. For the larger size modes, a57 and a212, the correlation between urban background and both kerbside and rural levels was high and levels were similar, especially for $\mathrm{NC}_{\mathrm{a} 212}$. $\mathrm{PM}_{10}$ levels were highly correlated and similar between urban background and rural levels. $\mathrm{PM}_{2.5}$ levels were highly correlated with a small ratio between urban background and kerbside levels, whereas $\mathrm{PM}_{10}$ levels showed weaker correlation and a larger ratio, indicating a contribution of coarse particles from traffic.

No effect of $\mathrm{NC}_{\text {tot }}$ was detected on CVD admissions (table 3). Significant positive associations between $\mathrm{PM}_{10}$ and both CVD and $\mathrm{RD}$ admissions in one-pollutant models remained after adjustment for $\mathrm{NC}_{\text {tot. }}$. Significant effects of $\mathrm{NC}_{\text {tot }}$ on $\mathrm{RD}$ admissions detected in one-pollutant models diminished after 
Table 1 Descriptive statistics for health outcomes, meteorology and urban background pollutants in Copenhagen over 1327 study days (15 May 2001 to 31 December 2004)

\begin{tabular}{|c|c|c|c|c|c|c|c|}
\hline & \multirow[b]{2}{*}{ Days (n) } & \multirow[b]{2}{*}{ Mean (SD) } & \multicolumn{4}{|c|}{ Percentiles } & \multirow[b]{2}{*}{$\operatorname{IOR}^{*}$} \\
\hline & & & 25th & 50th & 75th & 99th & \\
\hline \multicolumn{8}{|l|}{ Health outcome } \\
\hline CVD admissions ( $\geqslant 65$ years) & 1327 & $59(24)$ & 35 & 65 & 77 & 103 & 42 \\
\hline $\mathrm{RD}$ admissions ( $\geqslant 65$ years) & 1327 & $22(9)$ & 16 & 22 & 28 & 44 & 12 \\
\hline Asthma admissions (5-18 years) & 1327 & $3(2)$ & 1 & 3 & 4 & 9 & 3 \\
\hline \multicolumn{8}{|l|}{ Meteorology } \\
\hline Temperature $\left({ }^{\circ} \mathrm{C}\right)$ & 1284 & $10(7)$ & 5 & 10 & 16 & 23 & 11 \\
\hline Relative humidity (\%) & 1284 & $73(10)$ & 66 & 74 & 82 & 93 & 16 \\
\hline \multicolumn{8}{|l|}{ Number concentration (particles $/ \mathrm{cm}^{3}$ ) } \\
\hline $\mathrm{NC} \dagger_{\text {tot }}$ & 578 & $8116(3502)$ & 5738 & 7358 & 9645 & 19895 & 3907 \\
\hline $\mathrm{NC}_{\mathrm{a} 12}$ & 578 & $493(315)$ & 308 & 463 & 650 & 1463 & 342 \\
\hline $\mathrm{NC}_{\mathrm{a} 23}$ & 578 & $2253(1364)$ & 1280 & 2057 & 3066 & 6096 & 1786 \\
\hline $\mathrm{NC}_{\mathrm{a} 57}$ & 578 & $5104(2687)$ & 3248 & 4562 & 6274 & 14410 & 3026 \\
\hline $\mathrm{NC}_{100}$ & 578 & $6847(2864)$ & 4959 & 6243 & 8218 & 16189 & 3259 \\
\hline $\mathrm{NC}_{\mathrm{a} 212}$ & 578 & $392(441)$ & 89 & 246 & 584 & 2248 & 495 \\
\hline \multicolumn{8}{|l|}{ Mass concentration $\left(\mu \mathrm{g} / \mathrm{m}^{3}\right)$} \\
\hline $\mathrm{PM}_{10}$ & 1169 & $24(14)$ & 16 & 21 & 29 & 72 & 13 \\
\hline $\mathrm{PM}_{2.5}$ & 453 & $10(5)$ & 7 & 9 & 12 & 28 & 5 \\
\hline \multicolumn{8}{|l|}{ Gases (ppb) } \\
\hline $\mathrm{CO}$ & 1230 & $290(100)$ & 220 & 260 & 340 & 610 & 120 \\
\hline $\mathrm{NO}_{2}$ & 1245 & $11(5)$ & 8 & 11 & 14 & 28 & 6 \\
\hline $\mathrm{NO}_{\mathrm{x}}$ & 1245 & $15(8)$ & 9 & 12 & 18 & 46 & 9 \\
\hline $\mathrm{O}_{3}$ & 493 & $24(10)$ & 18 & 24 & 30 & 48 & 12 \\
\hline $\mathrm{NO}_{\text {xKerbside }} \S$ & 1286 & $83(36)$ & 58 & 76 & 103 & 207 & 45 \\
\hline
\end{tabular}

* IQR, interquartile range, difference between 75th and 25th percentile.

$\nmid N C$, number concentration; tot, total (all particles 6-700 nm in diameter); a12, size mode with mean diameter of $12 \mathrm{~nm}$; a23, size mode with median diameter of $23 \mathrm{~nm}$; a57, size mode with median diameter of $57 \mathrm{~nm}$; a212, size mode with median diameter of $212 \mathrm{~nm}$.

$\$ \mathrm{NC}_{100}=\mathrm{a} 12+\mathrm{a} 23+0.797 * \mathrm{a} 57+0.084^{*} \mathrm{a} 212$.

$\S N 0_{x K \text { erbside, }} \mathrm{NO}_{\mathrm{x}}$ levels measured at kerbside monitor.

adjusting for $\mathrm{PM}_{10}$ or $\mathrm{PM}_{2.5}$. $\mathrm{PM}_{2.5}$ showed significant association with CVD comparable to that with $\mathrm{PM}_{10}$, and no effect on $\mathrm{RD}$. $\mathrm{NO}_{2}$ showed a significant adverse effect on $\mathrm{RD}$ admissions in one-pollutant models, which diminished (RR: 1.01, 95\% CI: 0.98 to 1.05$)$ after adjusting for $\mathrm{PM}_{10}(1.03,1.01$ to 1.06$)$ in twopollutant models. No significant associations were detected with paediatric asthma, but adverse effects of $\mathrm{NC}_{\text {tot }}$ were stronger than those of $\mathrm{PM}_{10}$.

A borderline significant adverse effect of $\mathrm{PM}_{2.5}$ on paediatric asthma was robust in the presence of $\mathrm{NC}_{\text {tot }}$ or $\mathrm{PM}_{10}$

$\mathrm{NC}_{\mathrm{a} 212}$ was significantly associated with all three outcomes in one-pollutant models and this was robust in the presence of other size fractions (table 4), whereas $\mathrm{NC}_{\mathrm{a} 57}$ was associated with RD only. However, the effects of $\mathrm{NC}_{\mathrm{a} 212}$ on CVD and $\mathrm{RD}$ admissions diminished in the presence of $\mathrm{PM}_{10}$ but remained robust in the presence of $\mathrm{PM}_{10}$ for paediatric asthma. Similarly, the effect of $\mathrm{NC}_{\mathrm{a} 57}$ diminished in the presence of $\mathrm{PM}_{10}$ for $\mathrm{RD}$ (NC $\mathrm{N}_{\mathrm{a} 7}$ : 1.02, 0.97-1.07; $\mathrm{PM}_{10}$ : 1.04, 1.00-1.09). Observed effects of $\mathrm{NC}_{100}$ (table 4) were almost identical to those for $\mathrm{NC}_{\text {tot }}$ (table 3 ). The lag patterns for $\mathrm{NC}_{\mathrm{a} 212}$ and $\mathrm{PM}_{10}$ were similar for all three endpoints (fig 2), while smaller size modes displayed a generally different lag pattern than $\mathrm{NC}_{\mathrm{a} 212}$ and $\mathrm{PM}_{10}$. All singleday lag associations are shown in fig 2 , where generally more immediate effects of air pollution on CVD were observed, with the strongest effect of $\mathrm{PM}_{10}$ at a 2-day lag, while more delayed effects were observed on $\mathrm{RD}$, where the strongest effect of $\mathrm{PM}_{10}$ was seen at a 4-day lag.

A number of sensitivity analyses were performed to explore the robustness of results to alternative population or pollution proxies. Analyses with data limited to the $38 \%$ of CVD and $28 \%$

Table 2 Ratio and Spearman correlation coefficient $(r)$ between pollutants measured at three (urban background, kerbside and rural) monitoring stations in Copenhagen

\begin{tabular}{|c|c|c|c|c|}
\hline & \multicolumn{2}{|c|}{$\begin{array}{l}\text { Kerbside/urban background ( } 22 \text { September } 2004 \text { to } \\
26 \text { December 2005), } n=105\end{array}$} & \multicolumn{2}{|c|}{$\begin{array}{l}\text { Rural/urban background (22 April } 2005 \text { to } \\
11 \text { September 2005), } n=47\end{array}$} \\
\hline & Ratio* & $r$ & Ratio & $\mathbf{r}$ \\
\hline $\mathrm{NC}^{\dagger}{ }_{\text {tot }}$ & 4.6 & 0.62 & 0.7 & 0.80 \\
\hline $\mathrm{NC}_{\mathrm{a} 12}$ & 25.2 & 0.25 & 1.0 & 0.22 \\
\hline $\mathrm{NC}_{\mathrm{a} 23}$ & 7.6 & 0.63 & 0.2 & 0.48 \\
\hline $\mathrm{NC}_{\mathrm{a} 57}$ & 2.9 & 0.75 & 0.8 & 0.91 \\
\hline $\mathrm{NC}_{\mathrm{a} 212}$ & 1.0 & 0.95 & 0.9 & 0.96 \\
\hline $\mathrm{PM}_{10}$ & 1.7 & 0.65 & 1.0 & 0.86 \\
\hline $\mathrm{PM}_{2.5}$ & 1.2 & 0.86 & - & - \\
\hline
\end{tabular}


Table 3 Adjusted associations* between urban background pollutants and hospital admissions in Copenhagen for three outcomes (15 May 2001 to 31 December 2004)

\begin{tabular}{|c|c|c|c|c|c|c|c|}
\hline \multirow[b]{2}{*}{ Pollutant } & \multirow[b]{2}{*}{$\operatorname{IQR} \dagger$} & \multirow[b]{2}{*}{ One-pollutant model } & \multicolumn{5}{|l|}{ Two-pollutant models } \\
\hline & & & $\mathrm{NC}_{\text {tot }}+\mathrm{PM}_{10}$ & $\mathrm{NC}_{\text {tot }}+\mathrm{PM}_{2.5}$ & $\mathrm{NC}_{\text {tot }}+\mathrm{CO}$ & $\mathrm{NC}_{\text {tot }}+\mathrm{NO}_{2}$ & $\mathrm{NC}_{\text {tot }}+\mathbf{O}_{3}$ \\
\hline \multicolumn{8}{|c|}{ CVD hospital admissions (age $\geqslant 65$ years) $\S$} \\
\hline & & & $\mathrm{n}=605$ & $\mathrm{n}=302$ & $\mathrm{n}=657$ & $\mathrm{n}=606$ & $\mathrm{n}=264$ \\
\hline $\mathrm{NC} \boldsymbol{\top}_{\text {tot }}$ & 3907 & $1.00(0.99$ to 1.02$)$ & $0.98(0.96$ to 1.01$)$ & $0.99(0.95$ to 1.03$)$ & $0.99(0.97$ to 1.02$)$ & $1.01(0.98$ to 1.03$)$ & $1.01(0.96$ to 1.06$)$ \\
\hline $\mathrm{PM}_{10}$ & 13 & $1.03(1.01 \text { to } 1.05)^{* *}$ & $1.04(1.02 \text { to } 1.06)^{* *}$ & & & & \\
\hline $\mathrm{PM}_{2.5}$ & 5 & $1.03(1.01 \text { to } 1.06)^{* *}$ & & $1.03(1.01 \text { to } 1.06)^{* *}$ & & & \\
\hline $\mathrm{CO}$ & 120 & 1.02 (0.99 to 1.04$)$ & & & $1.02(0.99$ to 1.06$)$ & & \\
\hline $\mathrm{NO}_{2}$ & 6 & $1.00(0.98$ to 1.03$)$ & & & & $1.00(0.96$ to 1.03$)$ & \\
\hline $\mathrm{O}_{3}$ & 12 & $1.02(0.95$ to 1.09$)$ & & & & & $1.02(0.95$ to 1.10$)$ \\
\hline \multicolumn{8}{|c|}{ RD hospital admissions (age $\geqslant 65$ years) $\dagger \dagger$} \\
\hline & & & $\mathrm{n}=564$ & $\mathrm{n}=310$ & $\mathrm{n}=676$ & $\mathrm{n}=622$ & $\mathrm{n}=269$ \\
\hline $\mathrm{NC}_{\text {tot }}$ & 3907 & $1.04(1.00 \text { to } 1.07)^{* *}$ & $1.00(0.96$ to 1.05$)$ & $0.97(0.89$ to 1.05$)$ & $1.03(0.98$ to 1.07$)$ & $1.00(0.95$ to 1.05$)$ & $0.95(0.87$ to 1.04$)$ \\
\hline $\mathrm{PM}_{10}$ & 13 & $1.06(1.02 \text { to } 1.09)^{* *}$ & $1.05(1.01 \text { to } 1.10)^{* *}$ & & & & \\
\hline $\mathrm{PM}_{2.5}$ & 5 & $1.00(0.95$ to 1.05$)$ & & $1.00(0.95$ to 1.06$)$ & & & \\
\hline $\mathrm{CO}$ & 120 & $1.04(0.99$ to 1.09$)$ & & & $1.02(0.96$ to 1.08$)$ & & \\
\hline $\mathrm{NO}_{2}$ & 6 & $1.06(1.01 \text { to } 1.12)^{* *}$ & & & & $1.06(0.99$ to 1.13$)$ & \\
\hline $\mathrm{O}_{3}$ & 12 & $0.92(0.79$ to 1.07$)$ & & & & & $0.90(0.77$ to 1.05$)$ \\
\hline \multicolumn{8}{|c|}{ Asthma hospital admissions (age $5-18$ years) $)$} \\
\hline & & & $\mathrm{n}=559$ & $\mathrm{n}=318$ & $\mathrm{n}=691$ & $\mathrm{n}=684$ & $\mathrm{n}=274$ \\
\hline $\mathrm{NC}_{\text {tot }}$ & 3907 & $1.07(0.98$ to 1.17$)$ & $1.03(0.92$ to 1.15$)$ & $1.04(0.85$ to 1.28$)$ & $1.09(0.99$ to 1.21$)$ & $1.07(0.96$ to 1.19$)$ & $1.08(0.87$ to 1.35$)$ \\
\hline $\mathrm{PM}_{10}$ & 13 & $1.02(0.93$ to 1.12$)$ & $1.01(0.91$ to 1.12$)$ & & & & \\
\hline $\mathrm{PM}_{2.5}$ & 5 & $1.15(1.00$ to 1.32$)$ & & $1.13(0.98$ to 1.32$)$ & & & \\
\hline $\mathrm{CO}$ & 120 & 1.00 (0.89 to 1.127$)$ & & & $0.94(0.81$ to 1.08$)$ & & \\
\hline $\mathrm{NO}_{2}$ & 6 & $1.04(0.92$ to 1.18$)$ & & & & $0.97(0.83$ to 1.14$)$ & \\
\hline $\mathrm{O}_{3}$ & 12 & $1.11(0.78$ to 1.58$)$ & & & & & $1.16(0.80$ to 1.69$)$ \\
\hline 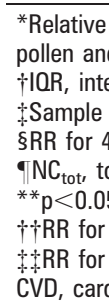 & $\begin{array}{l}\text { (RR) anc } \\
\text { ol holid } \\
\text { tile rang } \\
\text { i) for pc } \\
\text { average } \\
\text { Imber c } \\
\text { averag } \\
\text { averag } \\
\text { cular di }\end{array}$ & $\begin{array}{l}\% \text { confidence intervals } p \\
\text { for asthma. } \\
\text { difference between } 75 \text { th } \\
\text { tants in the one-pollutant } \\
\text { ean (lag } 0-3 \text { ). } \\
\text { entration of particles (6- } \\
\text { nean (lag } 0-4) \text {. } \\
\text { nean (lag } 0-5) \text {. } \\
\text { se; RD, respiratory disea }\end{array}$ & $\begin{array}{l}\text { er IQR, adjusted for temp } \\
\text { and } 25 \text { th percentile. } \\
\text { model is limited to day } \\
700 \mathrm{~nm} \text { in diameter). }\end{array}$ & when $\mathrm{NC}_{\text {tot }}$ is available, & $\begin{array}{l}\text { of the week, influenze } \\
\text { same as } n \text { in the two }\end{array}$ & $\begin{array}{l}\text { public holidays for all } \\
\text { ollutant model with N }\end{array}$ & outcomes, and gras \\
\hline
\end{tabular}

of RD admissions (not performed for paediatric asthma due to the low number of admissions) in hospitals within a radius of $5 \mathrm{~km}$ of the urban background monitor gave comparable RR values with wider confidence intervals due to the lower number of admissions (data not shown).

Finally, analyses with a complete series (15 May 2001 to 31 December 2004, $\mathrm{n}=1286$ ) of kerbside measurements of $\mathrm{NO}_{\mathrm{x}}$ showed strong positive associations with paediatric asthma admissions (1.22, 1.10 to 1.36) and weak associations with CVD (1.01, 0.99 to 1.03$)$ and $\mathrm{RD}(0.99,0.95$ to 1.02$)$ admissions. Estimates were reduced but positive for asthma and unchanged for CVD and RD when analyses were limited to days with available $\mathrm{NC}_{\text {tot }}$ (asthma: 1.08, 0.95 to 1.23, n=677; CVD: 0.99, 0.96 to $1.02, \mathrm{n}=643$; $\mathrm{RD}: 1.00,0.94$ to $1.05, \mathrm{n}=677$ ).

\section{DISCUSSION}

Our results indicated short-term associations between CVD and $\mathrm{RD}$ hospital admissions in the elderly and ambient levels of $\mathrm{PM}_{10}$ and accumulation mode particles, which suggests the relevance of volume and mass of PM for these endpoints, whereas particle numbers as measured in the urban background showed no effects. For paediatric asthma, results were less certain but indicated the relevance of accumulation mode and possibly $\mathrm{NC}_{100}$ and nitrogen oxides, suggesting the importance of traffic related sources, whereas $\mathrm{PM}_{10}$ showed little effect.
It was difficult to separate the effects of $\mathrm{PM}_{10}$ and $\mathrm{NC}_{\mathrm{a} 212}$ in this study since the two were closely correlated $(r=0.63)$. $\mathrm{NC}_{2212}$ represents the major fraction of $\mathrm{PM}_{10}$ and the two have almost identical lag structures (fig 2). Moreover, $\mathrm{NC}_{\mathrm{a} 212}$ levels varied very little between three measuring stations (table 2), confirming that this mode represents accumulation mode PM, mainly due to long-range transport in Copenhagen. Accordingly, in the two-pollutant models (table 4) we cannot exclude the possibility of artifactual association due to colinearity between $\mathrm{PM}_{10}$ and $\mathrm{NC}_{2212}$. However, weak correlation between $\mathrm{NC}_{\text {tot }}$ and both $\mathrm{PM}_{10}$ and $\mathrm{PM}_{2.5}$ indicated a different time course for the number concentration and mass of PM and allowed separation and comparison of their health effects. As we have shown earlier, $\mathrm{PM}_{10}$ and $\mathrm{PM}_{2.5}$ in Copenhagen originate mainly from long-range transported pollution from secondary sources, biomass and oil combustion and very slightly from local traffic, ${ }^{34}$ whereas $\mathrm{NC}_{100}$ comes primarily from local traffic. Overall, our results thus suggest that the adverse effects of PM on CVD and RD admissions in the elderly were mediated by accumulation mode or coarse (diameter $>2.5 \mathrm{~nm}$ ) PM, whereas no independent effect of number concentration of UFPs could be identified. The importance of the mass of PM is consistent with the numerous time series studies showing health effects associated with $\mathrm{PM}_{2.5}$ or $\mathrm{PM}_{10 .}{ }^{12}$ 
Table 4 Adjusted associations* between urban background pollutants and hospital admissions in Copenhagen for three outcomes (15 May 2001 to 31 December 2004)

\begin{tabular}{|c|c|c|c|c|}
\hline \multirow[b]{2}{*}{ Pollutant } & \multirow[b]{2}{*}{$\operatorname{IQR} \dagger$} & \multirow[b]{2}{*}{ One-pollutant model } & \multicolumn{2}{|l|}{ Multi-pollutant models } \\
\hline & & & Four size modes & $\mathrm{PM}_{10}+\mathrm{a} 212$ \\
\hline \multicolumn{5}{|c|}{ CVD hospital admissions (age $\geqslant 65$ years) $\S$} \\
\hline & & & $n=676$ & $n=564$ \\
\hline $\mathrm{PM}_{10}$ & 13 & $1.03(1.01 \text { to } 1.05)^{* *}$ & & $1.05(1.01 \text { to } 1.09)^{* *}$ \\
\hline $\mathrm{NC}_{100}$ & 3259 & $1.00(0.98$ to 1.02$)$ & & \\
\hline $\mathrm{NC} \uparrow_{\mathrm{a} 12}$ & 342 & $0.99(0.97$ to 1.01$)$ & $0.99(0.97$ to 1.02$)$ & \\
\hline $\mathrm{NC}_{\mathrm{a} 23}$ & 1786 & $0.99(0.96$ to 1.01$)$ & $0.99(0.96$ to 1.02$)$ & \\
\hline $\mathrm{NC}_{\mathrm{a} 57}$ & 3026 & $1.01(0.98$ to 1.02$)$ & $0.99(0.97$ to 1.02$)$ & \\
\hline $\mathrm{NC}_{\mathrm{a} 212}$ & 495 & $1.02(1.00 \text { to } 1.04)^{* *}$ & $1.02(1.00 \text { to } 1.05)^{* *}$ & $0.98(0.95$ to 1.01$)$ \\
\hline \multicolumn{5}{|c|}{ RD hospital admissions (age $\geqslant 65$ years) $\uparrow \dagger$} \\
\hline & & & $\mathrm{n}=701$ & $\mathrm{n}=564$ \\
\hline $\mathrm{PM}_{10}$ & 13 & $1.05(1.02 \text { to } 1.09)^{* *}$ & & $1.04(0.98$ to 1.11$)$ \\
\hline $\mathrm{NC}_{100}$ & 3259 & $1.03(0.99$ to 1.07$)$ & & \\
\hline $\mathrm{NC}_{\mathrm{a} 12}$ & 342 & $1.01(0.98$ to 1.05$)$ & $1.01(0.97$ to 1.05$)$ & \\
\hline $\mathrm{NC}_{\mathrm{a} 23}$ & 1786 & $0.99(0.94$ to 1.03$)$ & $0.98(0.94$ to 1.03$)$ & \\
\hline $\mathrm{NC}_{\mathrm{a} 57}$ & 3026 & $1.04(1.00 \text { to } 1.08)^{* *}$ & $1.02(0.97$ to 1.06$)$ & \\
\hline $\mathrm{NC}_{\mathrm{a} 212}$ & 495 & $1.04(1.01 \text { to } 1.08)^{* *}$ & $1.03(0.99$ to 1.07$)$ & $1.01(0.96$ to 1.07$)$ \\
\hline \multicolumn{5}{|c|}{ Asthma hospital admissions (age 5-18 years) +} \\
\hline & & & $\mathrm{n}=722$ & $\mathrm{n}=559$ \\
\hline $\mathrm{PM}_{10}$ & 13 & $1.02(0.93$ to 1.12$)$ & & $0.94(0.81$ to 1.09$)$ \\
\hline $\mathrm{NC}_{100}$ & 3259 & $1.06(0.97$ to 1.16$)$ & & \\
\hline $\mathrm{NC}_{\mathrm{a} 12}$ & 342 & $1.08(0.99$ to 1.18$)$ & $1.07(0.97$ to 1.19$)$ & \\
\hline $\mathrm{NC}_{\mathrm{a} 23}$ & 1786 & $1.09(0.98$ to 1.21$)$ & $1.08(0.97$ to 1.21$)$ & \\
\hline $\mathrm{NC}_{\mathrm{a} 57}$ & 3026 & $1.02(0.94$ to 1.12$)$ & $0.93(0.83$ to 1.04$)$ & \\
\hline $\mathrm{NC}_{\mathrm{a} 212}$ & 495 & $1.08(1.00 \text { to } 1.17)^{* *}$ & $1.12(1.02 \text { to } 1.23)^{* *}$ & $1.10(0.96$ to 1.13$)$ \\
\hline
\end{tabular}

\footnotetext{
${ }^{*}$ Relative risks (RR) and 95\% confidence intervals per IQR adjusted for temperature, dew point, season, day of the week, influenza, public holidays for all three outcomes, and grass pollen and school holidays for asthma.

HIOR, interquartile range, difference between 75th and 25th percentile.

$\$$ Sample size $(\mathrm{n})$ for pollutants in the one-pollutant model is limited to days when $\mathrm{NC}_{\text {tot }}$ is available.

$\S R R$ for 4-day average, mean (lag 0-3).

-NC, number concentration of particles; a12, size mode with median diameter of $12 \mathrm{~nm}$; a23, size mode with median diameter of 23 nm; a57, size mode with median diameter of $57 \mathrm{~nm}$; a212, size mode with median diameter of $212 \mathrm{~nm}$.

${ }^{* *} \mathrm{p}<0.05$.

+ RR for 5-day average, mean (lag $0-4)$

AtRR for 6-day average, mean (lag 0-5).

CVD, cardiovascular disease; RD, respiratory disease.
}

Exposure misclassification is an important challenge in epidemiological studies of the health effects of UFPs. ${ }^{35}$ As all epidemiological studies of UFP health effects to date have used central site UFP levels as exposure proxies, ${ }^{14-27}$ the extent of bias in risk estimates due to exposure misclassification remains unknown. Due to large spatial and temporal variations in UFPs, central site concentrations were found to be poorer proxies of personal exposure as compared to $\mathrm{PM}_{2.5}$ or $\mathrm{PM}_{10}$ in time series studies. ${ }^{35}$ In contrast, a study from Helsinki argued against exposure misclassification based on high correlations between UFP levels at four measuring sites. ${ }^{36}$ In the present study, the strong correlation between $\mathrm{NC}_{\mathrm{a} 212}$ measured at different stations in Copenhagen (table 2) suggests that population exposure to accumulation mode particles can be assessed reasonably well by one urban background monitoring station. Furthermore, the indoor penetration of this size range is high. ${ }^{37}$ In contrast, the number concentrations of size ranges in the UFP fraction (a12, a23 and a57) showed large spatial variation evident in poor correlation between the three monitoring stations, especially for the smallest modes (table 2). Moreover, the penetration of UFPs indoors seems to be lower than that for larger fractions, although there are important indoor sources. ${ }^{37-39}$ As here we used one urban background monitor for an admission radius of up to $15 \mathrm{~km}$, we can not exclude the possibility that the reported lack of effects of UFPs was due to exposure misclassification. However, the analysis with a hospital admission radius of $5 \mathrm{~km}$ from an urban background monitor (used in panel studies which reported the effects of UFPs $^{14-20}$ ) showed somewhat stronger but comparable effect estimates as our main analyses with a $15 \mathrm{~km}$ radius (results not shown). Assuming exposure misclassification in this study to be higher for smaller size modes, and random, it would bias the risk estimates towards zero.

Additional analyses were performed with kerbside measurements of $\mathrm{NO}_{\mathrm{x}}$, an alternative proxy of traffic pollution, for which we had a complete measurement series (1286 days). Since $\mathrm{NO}_{\mathrm{x}}$ and $\mathrm{NC}_{\text {tot }}$ both originate primarily from traffic and have comparable temporal and spatial variation, similar health effects from the two are expected. Our kerbside levels of $\mathrm{NO}_{\mathrm{x}}$, which were independent of wind direction, are not representative (too high) of personal exposures in this population, but are likely to capture the temporal exposure contrasts due to fresh traffic exhaust in the average street better than $\mathrm{NC}_{\text {tot }}$ measurements at a high background monitor. The kerbside $\mathrm{NO}_{x}$ showed significant positive associations with paediatric asthma admissions (estimates reported in Results), and weak associations with CVD and $\mathrm{RD}$ admissions. This suggests that the observed lack of effect of $\mathrm{NC}_{\text {tot }}$ on $\mathrm{CVD}$ and $\mathrm{RD}$ admissions in our elderly subjects (table 3 ) is likely to be real and not due to exposure misclassification bias. On the other hand, the strong 

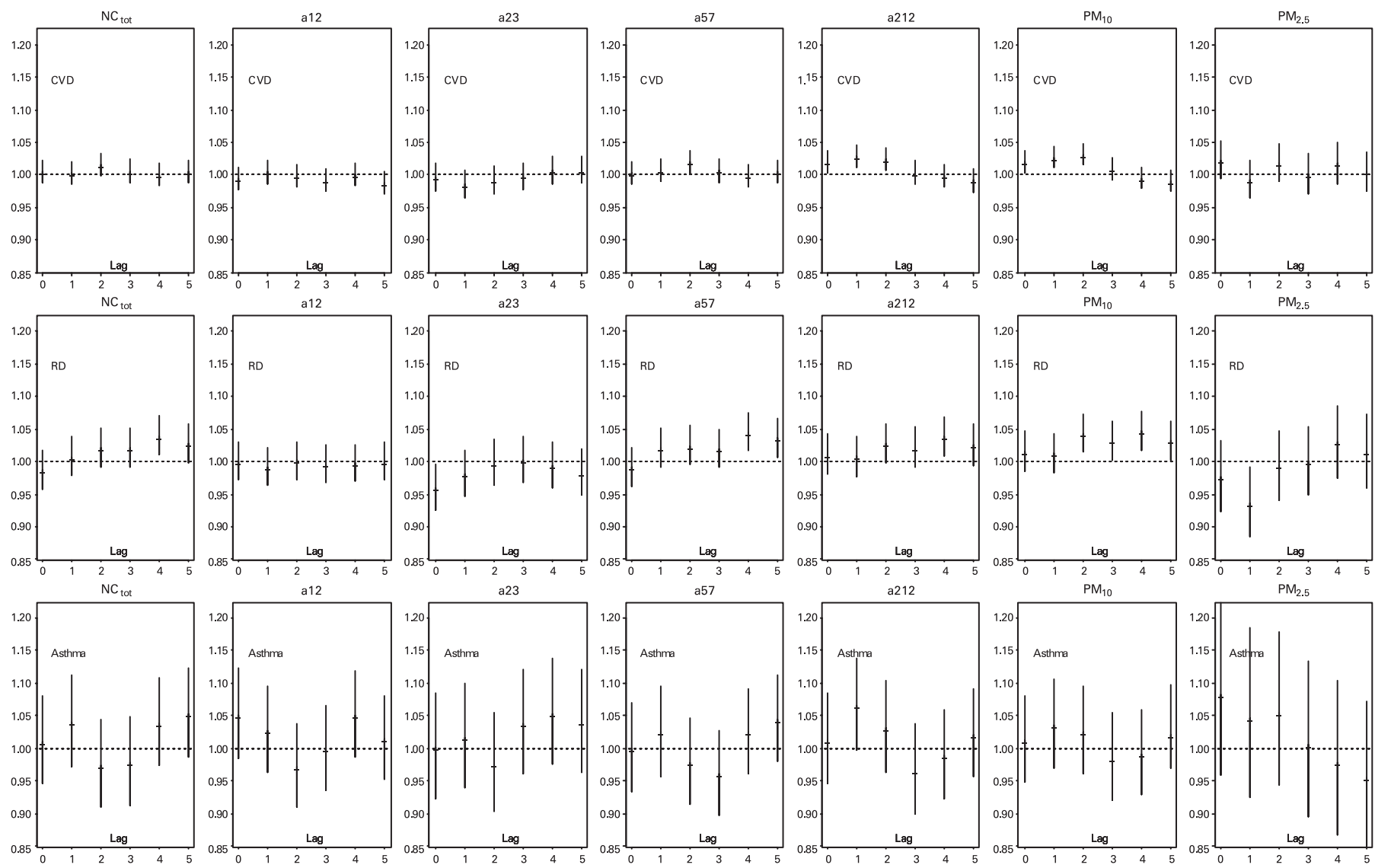

Figure 2 Relative risks and 95\% confidence intervals per interquartile range increment in single day concentrations (0-5-day lag) adjusted for temperature, dew-point temperature, season, day of the week, public holidays, influenza for all three outcomes, and grass pollen and school holidays for paediatric asthma (15 May 2001 to 31 December 2004).

effect of $\mathrm{NO}_{x}$ indicates the importance of traffic for paediatric asthma, as documented earlier, ${ }^{40}{ }^{41}$ and furthermore, probable underestimation of relative risks observed for $\mathrm{NC}_{\text {tot }}$ in this group (table 3) due to exposure misclassification bias.

The urban background particle number concentration levels in Copenhagen were generally smaller than those observed in other cities. ${ }^{42}{ }^{43}$ The Copenhagen urban background site at a height of $20 \mathrm{~m}$ is generally higher (Erfurt $4 \mathrm{~m}$, Augsburg $2 \mathrm{~m}$, Amsterdam $7.7 \mathrm{~m}$, Helsinki $4.5 \mathrm{~m}$ and $13 \mathrm{~m}$, Barcelona $15 \mathrm{~m}$, Rome $3 \mathrm{~m}$ ) or as high (Stockholm and Barcelona) as in other cities. ${ }^{43}{ }^{44}$ Some variation in particle numbers between cities is explained by meteorological and geographical conditions as well as the position of the monitoring site, both with respect to height and in relation to local sources, especially traffic. ${ }^{42}{ }^{43}$ Questions about how the position of background monitors affects the relevance of UFP measurements for health effect studies and the extent of exposure misclassification merits more research.

The existing evidence on UFP effects on CVD shows mixed results. Few studies have assessed the effects of individual size modes and the independence of effects in multi-pollutant models. Two papers from the HEAPSS (Health Effects of Particles on Susceptible Populations) multi-centre study reported the effects of UFPs on first myocardial infarction ${ }^{26}$ and hospital readmission among myocardial infarction survivors..$^{25} \mathrm{~A}$ related case-crossover study of out-of-hospital coronary deaths found stronger associations with UFPs than with $\mathrm{PM}_{10}{ }^{27}$ Two cardiovascular mortality studies offer conflicting results, with the initial report showing similar effects of UFPs and
$\mathrm{PM}_{2.5}{ }^{23}$ and the recent follow-up showing only associations with UFPs and none with $\mathrm{PM}_{10}$ or $\mathrm{PM}_{2.5}{ }^{24}$ Two multi-city panel studies in elderly subjects with coronary heart disease, based on the European ULTRA (Exposure and Risk Assessment for Fine and Utrafine Particles in Ambient Air) collaboration, showed results consistent with our findings in favour of larger cuts PM. De Hartog et al showed stronger associations of cardiorespiratory symptoms with $\mathrm{PM}_{2.5}$ than with UFPs ${ }^{18}$ while Ibald-Mulli et al in the same panel failed to find adverse effects of either UFPs or FPs on blood pressure or heart rate. ${ }^{19}$ On the other hand, another ULTRA study on the same panel reported strong associations of decreased heart rate variability, a predictor of mortality, with UFPs and weak associations with fine and coarse PM. ${ }^{21}$ Finally, a fourth ULTRA study, limited to a panel of the elderly in Helsinki, found the strongest associations between exercise induced ST-segment depression (proxy for myocardial ischaemia hospital admissions) and accumulation mode particles and FPs, weaker effects for UFPs, and none for coarse PM. ${ }^{17}$ These mixed results merit further research and point possibly to the relevance of different PM size cuts for different CVD definitions and outcomes (mortality vs morbidity) and/or different localities.

With respect to $\mathrm{RD}$, the epidemiological literature on UFP effects is sparse. A study from Erfurt showed an association between respiratory mortality and $\mathrm{NC}_{\text {tot }}$ and most of the size ranges as well as the cumulated volume of number concentration of particles interpreted as $\mathrm{PM}_{2.5}{ }^{24}$ Three panel studies on adults with asthma point, in contrast to our report, to the relevance of UFPs. Peters et al reported associations between a 


\section{Main messages}

- Particulate matter has been associated with short term morbidity and mortality, but there is limited evidence concerning ultrafine particles.

- This study found that particulate matter related cardiovascular and respiratory hospital admissions in the elderly were not mediated by ultrafine particles but rather by the mass of larger fractions.

- For paediatric asthma admissions, results indicated the relevance of accumulation mode particles as well as ultrafine particles and nitrogen oxides (relevant for traffic related sources).

\section{Policy implications}

- Reducing particulate matter levels may contribute to reducing associated morbidity.

- Control of particulate matter of all size cuts is necessary as different size cuts seem relevant for different health outcomes.

decrease in peak expiratory flow (PEF) and an increase in selfreported symptoms for both UFPs and $\mathrm{PM}_{10}$ (stronger for UFPs). ${ }^{14}$ Similarly, Penttinen et al found an association between PEF deviations and UFPs, but none with accumulation mode, FPs or coarse particles, while no effects were detected on asthma symptoms or medication use. ${ }^{15}$ Von Klot et al reported stronger associations for UFPs and FPs than for coarse particles with both asthma medication use and symptoms. ${ }^{16}$ Differences in the results of these studies compared with ours may be partially explained by different endpoints, as the three studies ${ }^{14-16}$ focused on symptoms in adults with asthma, whereas ours considered hospital admissions mainly for RDs other than asthma. On the other hand, two multi-centre ULTRA panel studies on respiratory symptoms in elderly subjects with coronary heart disease showed results similar to ours. De Hartog et al found stronger associations between cardiorespiratory symptoms and $\mathrm{PM}_{2.5}$ than with UFPs, ${ }^{18}$ while Timonen et al reported associations between urinary concentrations of lung Clara cell protein CC16, a marker of lung damage, and $\mathrm{PM}_{2.5}$ but none with UFPs. ${ }^{20}$ This set of results is too varied to provide conclusions but may indicate the relevance of particle numbers for asthma and mass for other RDs.

Our results for paediatric asthma showed higher effect estimates for $\mathrm{PM}_{2.5}, \mathrm{NC}_{\mathrm{a} 212}, \mathrm{NC}_{\text {tot }}$ and $\mathrm{NC}_{100}$ than for $\mathrm{PM}_{10}$, with accumulation mode $\mathrm{PM}$ in terms of $\mathrm{NC}_{\mathrm{a} 212}$ indicating the strongest effects. A single study to date assessing UFP effects in children, in contrast to ours, reported weak associations of FPs and UFPs with deficits in peak expiratory flow, and strong associations with $\mathrm{PM}_{10}{ }^{22}$ However, in a study of source apportionment of $\mathrm{PM}_{10}$ we have previously found the strongest associations to be between vehicle sources (traffic exhaust) and paediatric asthma admissions. ${ }^{34}$ This is in keeping with the strong association with kerbside $\mathrm{NO}_{\mathrm{x}}$ in the present study and with current evidence on the importance of traffic related pollution and childhood asthma. ${ }^{40} 41$

The limitations of the present study include limited statistical power due to a relatively short and incomplete $\mathrm{NC}_{\text {tot }}$ time series caused by difficulties in long-term particle counting, as experienced elsewhere. ${ }^{43}$ Further lack of power in estimating effects for paediatric asthma is the result of a low number of admissions. However, a strength of the present study is that it is unique in linking measured number concentration and the mass of different size modes of UFPs and FPs to three morbidity outcomes at a single location, providing the possibility of comprehensive direct comparisons of pollution effects across diseases (CVD and RD in the elderly, and paediatric asthma).

\section{CONCLUSION}

In conclusion, we found that the adverse health effects of PM on CVD and $\mathrm{RD}$ hospital admissions in the elderly in Copenhagen were mediated mainly by $\mathrm{PM}_{10}$ and/or accumulation mode particles, whereas the number concentration of urban background UFPs seemed less relevant. For paediatric asthma, the results indicated the relevance of accumulation mode and possibly UFPs and nitrogen oxides (relevant for traffic related sources), but results were less certain than for the elderly. Exposure misclassification bias in this study may have caused underestimation of the effects of UFPs in paediatric asthma, whereas the lack of effects of UFPs for CVD and RD admissions is believed to be correct.

Funding: This study was supported by the Danish Research Council, grant no. 2052 03-16, AIRPOLIFE (Air Pollution in a Life Time Health Perspective). ZJA and SL are partners of ECNIS (Environmental Cancer Risk, Nutrition and Individual Susceptibility), a network of excellence operating within the European Union 6th Framework Program, Priority 5: "Food Quality and Safety" (contract no. 513943).

Competing interests: None declared.

\section{REFERENCES}

1. Brunekreef B, Holgate ST. Air pollution and health. Lancet 2002;360:1233-42

2. Schwartz J. Air pollution and children's health. Paediatrics 2004;113/4 Suppl):1037-43.

3. Delfino RJ, Sioutas C, Malik S. Potential role of ultrafine particles in associations between airborne particle mass and cardiovascular health. Environ Health Perspect 2005;113(8):934-46.

4. Sioutas C, Delfino RJ, Singh M. Exposure assessment for atmospheric ultrafine particles (UFPs) and implications in epidemiologic research. Environ Health Perspect 2005;113(8):947-55.

5. Donaldson K, Stone V, Clouter A, et al. Ultrafine particles. Occup Environ Med 2001;58(3):211-16.

6. Nemmar A, Hoet PH, Vanquickenborne B, et al. Passage of inhaled particles into the blood circulation in humans. Circulation 2002;105:411-14.

7. Daigle CC, Chalupa DC, Gibb FR, et al. Ultrafine particle deposition in humans during rest and exercise. Inhal Toxicol 2003:15:539-52.

8. Donaldson K, Stone V. Current hypotheses on the mechanisms of toxicity of ultrafine particles. Ann Ist Super Sanita 2003;39(3):405-10.

9. Li N, Sioutas $C$, Cho A, et al. Ultrafine particulate pollutants induce oxidative stress and mitochondrial damage. Environ Health Perspect 2003;111:455-60.

10. Chalupa DC, Morrow PE, Oberdörster G, et al. Ultrafine particle deposition in subjects with asthma. Environ Health Perspect 2004;112:879-82.

11. Oberdorster G, Oberdorster E, Oberdorster J. Nanotoxicology: an emerging discipline evolving from studies of ultrafine particles. Environ Health Perspect 2005;113(7):823-39.

12. Vinzents PS, Moller P, Sorensen M, et al. Personal exposure to ultrafine particles and oxidative DNA damage. Environ Health Perspect 2005;113(11):1485-90.

13. Schlesinger RB, Kunzli N, Hidy GM, et al. The health relevance of ambient particulate matter characteristics: coherence of toxicological and epidemiological inferences. Inhal Toxicol 2006;18:95-125.

14. Peters A, Wichmann HE, Tuch T, et al. Respiratory effects are associated with the number of ultrafine particles. Am J Respir Crit Care Med 1997;155:1376-83.

15. Penttinen $\mathbf{P}$, Timonen $\mathrm{KL}$, Tïttanen $\mathbf{P}$, et al. Ultrafine particles in urban air and respiratory health among adult asthmatics. Eur Respir J 2001;17:428-35.

16. Von Klot S, Wolke G, Tuch T, et al. Increased asthma medication use in association with ambient fine and ultrafine particles. Eur Respir J 2002;20:691-702.

17. Pekkanen J, Peters A, Hoek G, et al. Particulate air pollution and risk of ST-segment depression during repeated submaximal exercise tests among subjects with coronary heart disease: the Exposure and Risk Assessment for Fine and Ultrafine Particles in Ambient Air (ULTRA) study. Circulation 2002;106:933-8.

18. De Hartog JJ, Hoek G, Peters A, et al. Effects of fine and ultrafine particles on cardiorespiratory symptoms in elderly subjects with coronary heart disease: the ULTRA study. Am J Epidemiol 2003;157:613-23.

19. Ibald-Mulli A, Timonen KL, Peters A, et al. Effects of particulate air pollution on blood pressure and heart rate in subjects with cardiovascular disease: a multicenter approach. Environ Health Perspect 2004;112(3):369-77. 
20. Timonen $\mathbf{K L}$, Hoek $\mathrm{G}$, Heinrich J, et al. Daily variation in fine and ultrafine particulate air pollution and urinary concentrations of lung Clara cell protein CC16. Occup Environ Med 2004;61:908-14

21. Timonen KL, Vanninen $\mathrm{E}$, de Hartog J, et al. Effects of ultrafine and fine particulate and gaseous air pollution on cardiac autonomic control in subjects with coronary artery disease: the ULTRA study. J Expo Anal Environ Epidemiol 2006;16:332-41.

22. Pekkanen J, Timonen KL, Ruuskanen J, et al. Effects of ultrafine and fine particles in urban air on peak expiratory flow among children with asthmatic symptoms. Environ Res 1997;74:24-33.

23. Wichmann HE, Spix C, Tuch T, et al. Daily mortality and fine and ultrafine particles in Erfurt, Germany part I: role of particle number and particle mass. Res Rep Health Eff Inst 2000;(98):5-86.

24. Stolzel M, Breitner S, Cyrys J, et al. Daily mortality and particulate matter in different size classes in Erfurt, Germany. J Expo Sci Environ Epidemiol 2007:17:458-67.

25. Von Klot S, Peters A, Aalto $\mathrm{P}$, et al. Ambient air pollution is associated with increased risk of hospital cardiac readmissions of myocardial infarction survivors in five European cities. Circulation 2005;112:3073-9.

26. Lanki T, Pekkanen J, Aalto P, et al. Associations of traffic related air pollutants with hospitalisation for first acute myocardial infarction: the HEAPSS study. Occup Environ Med 2006;63:844-51.

27. Forastiere $\mathbf{F}$, Stafoggia M, Picciotto $\mathbf{S}$, et al. A case-crossover analysis of out-ofhospital coronary deaths and air pollution in Rome, Italy. Am J Respir Crit Care Med 2005;172:1549-55.

28. World Health Organization. International statistical classification of disease and related health problems, tenth revision (ICD-10). Geneva: WHO, 1992.

29. World Health Organization. Air quality guidelines for Europe. 2nd ed. European Series No. 91. Copenhagen: WHO Regional Office for Europe, 2000.

30. Ketzel M, Wahlin P, Berkowicz R, et al. Particle and trace gas emission factors under urban driving conditions in Copenhagen based on street and roof-level observations. Atmos Environ 2003;37:2735-49.

31. Wahlin $\mathbf{P}$, Ketzel M, Palmgren F. Dependence on meteorological conditions of traffic particle profiles measured in a street canyon in Copenhagen. Nat Environ Sci 2004;172:142-5

32. Hastie T, Tibshirani R. Generalized additive models. London: Chapman and Hall, 1990.

33. R Development Core Team. $R$ : A language and environment for statistical computing, version 2.3.0. Vienna, Austria: R Foundation for Statistical Computing, 2006.

34. Andersen ZJ, Wahlin P, Raaschou-Nielsen 0, et al. PM ambient particle source apportionment and daily hospital admissions among children and elderly in Copenhagen. J Expo Sci Environ Epidemiol 2007;17:625-36.

35. Pekkanen J, Kulmala M. Exposure assessment of ultrafine particles in epidemiologic time-series studies. Scand J Work Environ Health 2004;30(Suppl2):9-18.

36. Buzorious G, Hameri K, Pekkanen J, et al. Spatial variation of aerosol number concentration in Helsinki city. Atmos Environ 1999;33:553-65.

37. Hussein T, Hameri K, Heikkinen MSA, et al. Indoor and outdoor particle size characterization at a family house in Espoo, Finland. Atmos Environ 2005;39:3697-709.

38. Palmgren $\mathbf{F}$, Wåhlin $\mathrm{P}$, Kildesø J, et al. Characterization of particle emissions from the driving car fleet and the contribution to ambient and indoor particle concentrations. Phys Chem Earth 2003;28:327-34.
39. Schneider T, Jensen KA, Clausen PA, et al. Prediction of indoor concentration of $0.5-4 \mu \mathrm{m}$ particles of outdoor origin in an uninhabited apartment. Atmos Environ 2004;38:6349-59.

40. McConnell R, Berhane K, Yao L, et al. Traffic, susceptibility, and childhood asthma Environ Health Perspect 2006;114(5):766-72.

41. Gauderman WJ, Avol E, Lurmann F, et al. Childhood asthma and exposure to traffic and nitrogen dioxide. N Engl J Med 2004;351(11):1057-67.

42. Ruuskanen J, Tuch TH, Ten Brink $\mathrm{H}$, et al. Concentrations of ultrafine, fine and $\mathrm{PM}_{2,5}$ particles in three European cities. Atmos Environ 2001:35:3729-38.

43. Aalto P, Hameri K, Paatero P, et al. Aerosol particle number concentration measurements in five European cities using TSI-3022 condensation particle counter over a three-year period during Health Effects of Air Pollution on Susceptible Subpopulations. J Air Waste Manag Assoc 2005;55(8):1064-76.

44. Pekkanen J, Timonen KL, Tiittane P, et al. ULTRA: exposure and risk assessment for fine and ultrafine particles in ambient air. Study manual and data book. Kuopio, Finland: National Public Health Institute, 2000. Available at http://www.ktl.fi/ultra.

\section{Appendix A}

Table A1 Surface area and volume concentration for total number concentration and four size modes of urban background particles in Copenhagen over 1327 study days (15 May 2001 to 31 December 2004)

\begin{tabular}{lll}
\hline & n (days) & Mean (25th-75th percentile) \\
\hline Surface area concentration $\left(\mu \mathrm{m}^{2} / \mathrm{cm}^{3}\right)$ & \\
$\mathrm{NC}_{\text {tot }}{ }^{*}$ & 578 & $213(117-271)$ \\
$\mathrm{NC}_{\mathrm{a} 12}$ & 578 & $0.2(0.1-0.3)$ \\
$\mathrm{NC}_{\mathrm{a} 23}$ & 578 & $4.9(2.8-6.7)$ \\
$\mathrm{NC}_{\mathrm{a} 57}$ & 578 & $130(82-159)$ \\
$\mathrm{NC}_{\mathrm{a} 212}$ & 578 & $99(23-148)$ \\
${\text { Volume concentration }\left(\mu \mathrm{m}^{3} / \mathrm{cm}^{3}\right)}$ & \\
$\mathrm{NC}_{\text {tot }}$ & 578 & $8.5(3.9-11.1)$ \\
$\mathrm{NC}_{\mathrm{a} 12}$ & 578 & $0.00(0.00-0.00)$ \\
$\mathrm{NC}_{\mathrm{a} 23}$ & 578 & $0.03(0.01-0.04)$ \\
$\mathrm{NC}_{\mathrm{a} 57}$ & 578 & $3.8(2.4-4.7)$ \\
$\mathrm{NC}_{\mathrm{a} 212}$ & 578 & $7.3(1.7-10.9)$ \\
\hline
\end{tabular}

${ }^{*} \mathrm{NC}$, number concentration; tot, total (all particles 6-700 nm in diameter); a12, size mode with mean diameter of $12 \mathrm{~nm}$; a23, size mode with mean diameter of $23 \mathrm{~nm}$; a57, size mode with mean diameter of $57 \mathrm{~nm}$; a212, size mode with mean diameter of $212 \mathrm{~nm}$.

Table A2 Spearman's rank correlation coefficient between urban background pollutants and meteorological variables in Copenhagen over 1327 study days (15 May 2001 to 31 December 2004)

\begin{tabular}{|c|c|c|c|c|c|c|c|c|c|c|c|c|c|c|}
\hline & $\mathrm{NC}_{\text {tot }}{ }^{*}$ & $\mathrm{NC}_{100} \dagger$ & $\mathrm{NC}_{\mathrm{a} 12}$ & $\mathrm{NC}_{\mathrm{a} 23}$ & $\mathrm{NC}_{\mathrm{a} 57}$ & $\mathrm{NC}_{\mathrm{a} 212}$ & $\mathrm{PM}_{10}$ & $\mathrm{PM}_{2.5}$ & CO & $\mathrm{NO}_{2}$ & $\mathrm{NO}_{\mathrm{x}}$ & $\mathrm{NO}_{\text {xKerbside }}$ & $\mathbf{O}_{3}$ & Temperature \\
\hline $\mathrm{NC}_{100}$ & 0.98 & - & & & & & & & & & & & & \\
\hline $\mathrm{NC}_{\mathrm{a} 12}$ & 0.31 & 0.35 & - & & & & & & & & & & & \\
\hline $\mathrm{NC}_{\mathrm{a} 23}$ & 0.57 & 0.64 & 0.18 & - & & & & & & & & & & \\
\hline $\mathrm{NC}_{\mathrm{a} 57}$ & 0.87 & 0.84 & 0.20 & 0.19 & - & & & & & & & & & \\
\hline $\mathrm{NC}_{\mathrm{a} 212}$ & 0.29 & 0.16 & 0.07 & -0.16 & 0.32 & - & & & & & & & & \\
\hline $\mathrm{PM}_{10}$ & 0.39 & 0.28 & 0.02 & -0.12 & 0.45 & 0.63 & - & & & & & & & \\
\hline $\mathrm{PM}_{2.5}$ & 0.40 & 0.29 & 0.07 & -0.25 & 0.51 & 0.82 & 0.80 & - & & & & & & \\
\hline $\mathrm{NO}_{2}$ & 0.68 & 0.61 & 0.10 & 0.41 & 0.56 & 0.36 & 0.35 & 0.42 & 0.70 & - & & & & \\
\hline $\mathrm{NO}_{\mathrm{x}}$ & 0.66 & 0.60 & 0.09 & 0.42 & 0.54 & 0.35 & 0.32 & 0.40 & 0.72 & 0.99 & - & & & \\
\hline $\mathrm{NO}_{\text {xkerbside: }}$ & 0.36 & 0.35 & 0.00 & 0.31 & 0.32 & 0.13 & 0.18 & 0.28 & 0.48 & 0.60 & 0.63 & - & & \\
\hline $\mathrm{O}_{3}$ & -0.12 & -0.06 & 0.16 & -0.20 & -0.02 & -0.24 & -0.21 & -0.20 & -0.57 & -0.55 & -0.58 & -0.33 & - & \\
\hline Temperature & -0.06 & -0.05 & 0.09 & -0.24 & 0.06 & -0.28 & 0.12 & -0.01 & -0.49 & -0.22 & -0.22 & -0.10 & 0.40 & - \\
\hline RelativeHumidity & -0.04 & -0.10 & 0.02 & -0.06 & -0.07 & 0.49 & 0.05 & 0.21 & 0.38 & 0.25 & 0.26 & 0.07 & -0.63 & -0.36 \\
\hline
\end{tabular}

*NC, number concentration of particles; tot, total (all particles $6-700 \mathrm{~nm}$ in diameter); a12, size mode with mean diameter of $12 \mathrm{~nm}$; a23, size mode with mean diameter of $23 \mathrm{~nm}$ a57, size mode with mean diameter of $57 \mathrm{~nm} ; \mathrm{a} 212$, size mode with mean diameter of $212 \mathrm{~nm}$

$\dagger N C_{100}=\mathrm{a} 12+\mathrm{a} 23+0.797 * \mathrm{a} 57+0.084 * \mathrm{a} 212$.

$\mathrm{NO} \mathrm{N}_{\text {xerbside, }} \mathrm{NO}_{\mathrm{x}}$ levels measured at kerbside monitor. 